\title{
Preparing and administering medications via enteral catheters: A guideline for the clinical pharmacists and the multi-professional team
}

\author{
Danyara BATISTA ${ }^{1}$ (D), Paula Macedo de OLIVEIRA-LEMOS ${ }^{1}$ (D) \\ ${ }^{1}$ Hospital Regional de São José Dr. Homero de Miranda Gomes \\ Corresponding author: Batista D, danyarabat@gmail.com
}

Submitted: 22-02-2021 Resubmitted: 16-04-2021 Accepted: 16-04-2021

Peer review: blind reviewers

\begin{abstract}
Objective: To identify the most prescribed drugs by enteral feeding tube in a public hospital and to a guideline for safe medication preparation and administration via enteral feeding tubes. Methods: A cross-sectional study with analysis of the daily prescriptions of patients exclusively using an enteral catheter in intensive care units and inpatients of the medical clinic specialty, in which descriptive statistics were used to identify the prevalence of medication use by tube. In a second step, a protocol was developed for the situation in which oral medications are prescribed to patients with a tube in the digestive tract. Results: A total of 1.810 medications prescribed by enteral feeding tube, of these 1.810, 291 (16\%) were prescribed in liquid pharmaceutical form (suspension, solution, syrup) e 1.519 (84\%) were prescribed in solid pharmaceutical form (tablets, capsule). 52 medications were selected for the protocol, and 14 of them $(26,9 \%)$ with the recommendation of not crushing and administering via enteral feeding tube. Conclusion: Our results highlights the performance of clinical pharmacist in monitoring patients with enteral feeding tubes and guidance of multi-professional team. The protocol elaboration will guide for preparation and administration medication through the enteral feeding tube, reducing possible adverse events and ensuring the safety and efficacy of drug therapy.
\end{abstract}

Keywords: enteral nutrition; hospital care; patient safety; pharmacy service, hospital; clinical pharmacy.

\section{Preparo e administração de medicamento via cateter enteral: um protocolo para farmacêuticos clínicos e equipe multiprofissional}

\begin{abstract}
Resumo
Objetivos: Identificar os medicamentos mais prescritos via cateter enteral em um hospital público e a partir disso elaborar um protocolo para preparo e administração de medicamentos por essa via de forma segura. Métodos: Estudo transversal com análise das prescrições diárias de pacientes em uso exclusivo de cateter enteral das unidades de terapia intensiva e de internação da especialidade de clínica médica no qual foram realizadas estatísticas descritivas para identificação de prevalência de uso de medicamentos por sonda. Em um segundo momento foi desenvolvido um protocolo para a situação em que há prescrição de medicamentos orais a pacientes com sonda no tubo digestivo. Resultados: Foram identificados 1.810 medicamentos prescritos via cateter enteral, dentre esses 291 (16\%) foram prescritos em forma farmacêutica líquida e 1.519 (84\%) foram prescritos em forma farmacêutica sólida. Destes, foram selecionados 52 medicamentos para o desenvolvimento do protocolo, onde 14 destes (26,9\%) tem recomendação de não triturar e administrar via cateter enteral. Conclusão: Nossos resultados destacam a importância do farmacêutico clínico no monitoramento de pacientes com cateter enteral e na orientação da equipe multiprofissional. O protocolo elaborado orientará o preparo e administração de medicamentos por cateter enteral, minimizando possíveis eventos adversos e garantindo a segurança e eficácia na terapia medicamentosa.
\end{abstract}

Palavras-chave: nutrição enteral; assistência hospitalar; segurança do paciente; serviço de farmácia hospitalar; farmácia clínica.

\section{Introduction}

The use of enteral catheters in patients admitted to a highcomplexity hospital is very common and has the objective of maintaining or recovering the patient's nutritional status. ${ }^{1}$ Usually, those who use this device are aged, oncologic, and more debilitated patients who need more attention to their general health status and who do not have a compromised gastrointestinal tract or other contraindication. ${ }^{2}$ In these patients, the adequate choice of the medications will bring about more safety in the effectiveness 
of the treatment and less exposure to adverse effects, possible obstructions of the enteral catheter, aspiration pneumonia, diarrhea or drug inefficiency, which are the main problems related

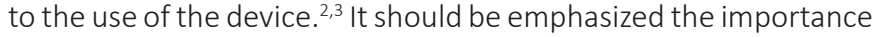
of developing tools to monitor this practice and ensure quality in therapeutic outcomes, reducing the number of complications and errors related to the use of drugs..$^{3,4}$

The enteral route is the most physiological and safest alternative route in relation to contamination risks and also represents a lower cost when compared to parenteral nutrition. ${ }^{5}$ The administration of medications by the same route as the enteral diet is a frequent routine in the dynamics of a hospital, which justifies the importance of strategies to achieve effectiveness of the pharmacological treatment and preserve this access. It is of major importance that the pharmacist participates in this process to guarantee the safety and effectiveness of the drug therapy. ${ }^{6}$

Thus, the performance of the pharmacist can contribute to patient safety, which is defined as a reduction of the risk of unnecessary harms associated with health care to an acceptable minimum, since it favors the promotion of safe practices within the hospital unit, contributing to the reduction of risks that can cause any harm to the patient, improving quality of care. ${ }^{7,8}$

Aiming at quality in the process of drug administration via enteral catheters, liquid pharmaceutical presentations must be used, but not all medications have this pharmaceutical form available in the market. Therefore, empirically, some pills are crushed and diluted in water to be administered. ${ }^{1,5}$

The change of the pharmaceutical presentation can imply risks to the professionals who are exposed to manipulation without a proper technique. ${ }^{1}$ In addition to the exposure of the health professional, crushing pills can increase the absorption speed providing higher plasma concentration of the drug, which increases the risk of toxicity and reduces the duration of the effect. ${ }^{9}$ When crushed, the drug depends on its solubility in water and penetration into the intestinal mucosa, because ineffective dissolution is the main factor for poor absorption. ${ }^{10}$

This study was justified by the need for knowledge and evaluation of the medications that are prescribed via enteral catheters in the selected inpatient units of the Dr. Homero de Miranda Gomes Regional Hospital of São José. Consequently, with the data obtained, a protocol was prepared with the guidelines for the professionals working in the assistance team with the objective of standardizing the process, minimizing possible risks to the patient and to the drug handler.

\section{Methods}

A prospective cross-sectional study conducted to develop a pharmaceutical guidance protocol for the preparation and administration of medications via enteral catheters in the Dr. Homero de Miranda Gomes Regional Hospital of São José. The medical prescriptions used were those of the patients in use of exclusive enteral catheters and hospitalized in the wards of the medical clinic specialty and intensive care unit.

The sample was selected for being characterized by hospitalization units in which the inpatients present more severe and complex conditions, being evaluated during the period of February and March 2020. The patients who were on enteral diet and associated oral diet and the medications prescribed with an "as needed" dosage were excluded.

The data collected from each medication prescribed were the following: name of the medication, pharmaceutical presentation, dosage, dose and administration route. They were recorded, tabulated and analyzed in a Microsoft Office Excel 2010 spreadsheet.

During the period from May to November 2020, they were listed among the most prescribed medications, and these were selected to develop the protocol. The authors elaborated a Pharmacy guidance protocol for the preparation and administration of medications via enteral catheters.

Among these, in the period from May to August 2020, the authors selected the medications that cannot be crushed, whose guidance was on the electronic package inserts registered at the National Health Surveillance Agency (Agência Nacional de Vigilância Sanitária, ANVISA) and in other references such as manuals and guides so that they could later be labeled with the "non-crushable" guidance during the unitarization process. The inserts researched and compared were in accordance with the frequently available laboratory exams in the hospital unit.

For the elaboration of this protocol, a search was conducted in the literature, with the following details: name of the generic drug, nutrição enteral/enteral nutrition, assistência hospitalar/ hospital care, segurança do paciente/patient safety, serviço de farmácia hospitalar/pharmacy service, hospital. Texts in English and in Portuguese published from 2010 to 2020 were selected in the research. The databases consulted were Pubmed, Upto date, Lilacs and Medline, as well as electronic package inserts. The search strategy and inclusion criteria for the selected medications were as follows: altered pharmacokinetics, reduced or lost efficacy, risk of enteral catheter obstruction, and drugnutrient interaction. In the occurrence of some inconsistency between the literature materials, we standardized the one that best applied to the work processes and structure offered by the hospital unit.

A flowchart was also prepared, presented in Figure 1, to guide the pharmacist in the practice of analyzing the prescription and dispensing of the medications for patients with enteral catheters, following the guidelines described in the protocol.

In this paper, the term "enteral catheter" will be used, maintaining "enteral tube" only in citations and references by other authors.

The study was approved by the Committee of Ethics and Research in Human Beings of the Santa Catarina Estácio de Sá University Center, São José Campus (Approval No. 3,946,344).

\section{Results}

In the collections performed, 1,810 medications prescribed via enteral catheters were identified, them being 96 different drugs. The analyzed data were tabulated and divided according to therapeutic classes in accordance with the Anatomical Therapeutic Chemical (ATC) classification, a model adopted by the World Health Organization (WHO) and used internationally to classify molecules with therapeutic action. ${ }^{10}$ 
Figure 1. Guiding flowchart for pharmacists in dispensing medications to patients with enteral catheters.

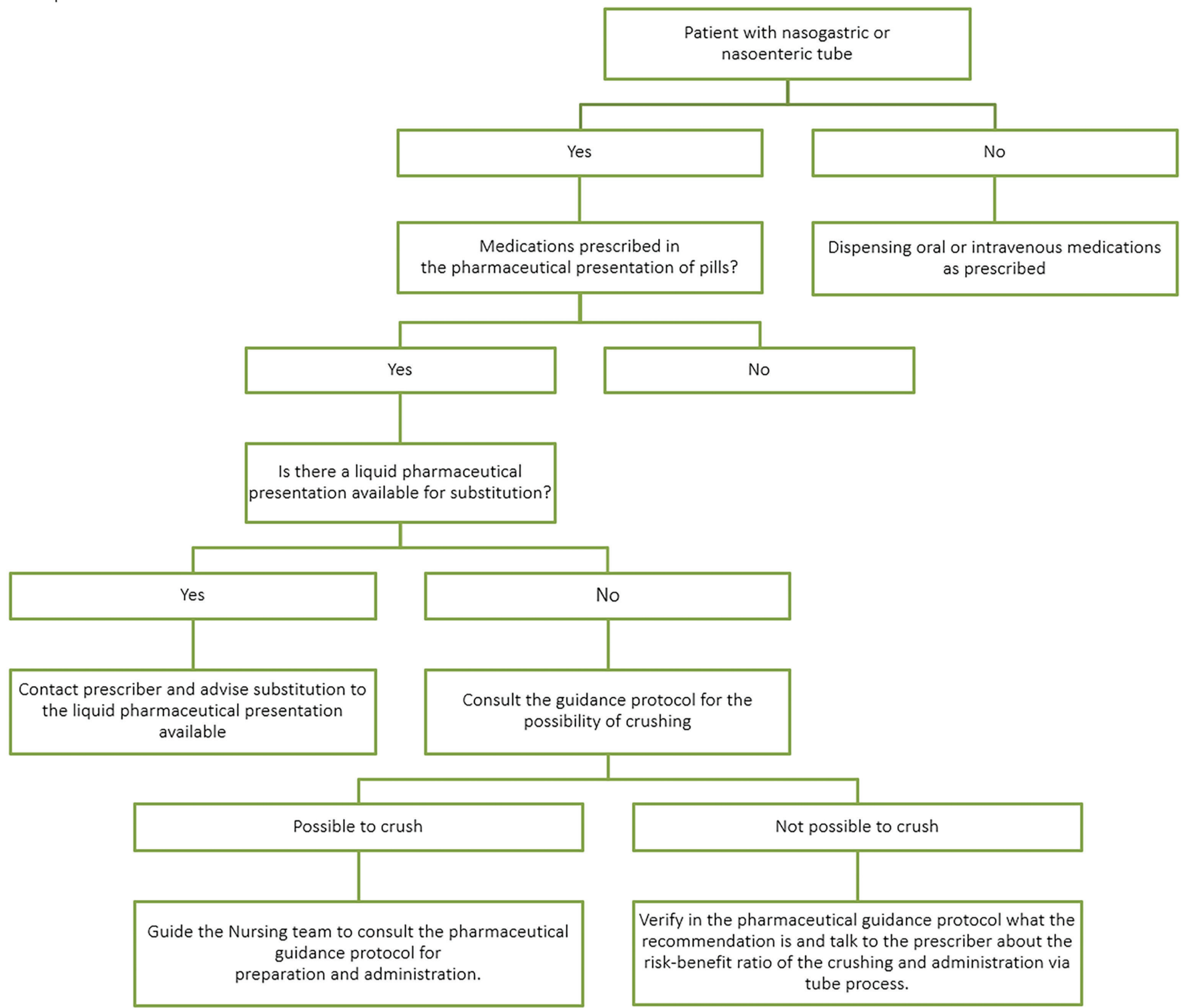

Among these 1,810 medications, 291 (16\%) were prescribed in liquid pharmaceutical presentations (suspension, solution, syrup) and 1,519 (84\%) were prescribed in solid pharmaceutical presentations (pills, dragées, capsules). The classes of most frequently prescribed medications were cardiovascular system with $32.8 \%$, nervous system with $27.36 \%$ and feeding tract and metabolism with $16.4 \%$, comprising $76.56 \%$ of the medications prescribed via enteral catheters.

A total of 52 medications were included in the protocol; 14 (36.5\%) of these drugs present interactions with enteral nutrition and can be considered harmful or not, and are distributed in the following therapeutic classes: $50 \%(n=7)$, cardiovascular system; $21.5 \%(n=3)$, nervous system; $14.3 \%(n=2)$, digestive tract and metabolism; $7.1 \%(n=1)$, blood and blood-forming organs; and $7.1 \%(n=1)$, systemic hormone preparations.

Another 5 medications (9.6\%) in the protocol were prescribed without interventions and can cause enteral catheter obstruction, which are part of the following classes: $40 \%(n=2)$, digestive tract and metabolism; $20 \%(n=1)$, cardiovascular system; $20 \%$ $(n=1)$, nervous system; and $20 \%(n=1)$, anti-infective agents for systemic use.

In addition, according to the literature, 14 (26.9\%) of the medications included in the protocol are not recommended for crushing and administration via enteral catheters, which are distributed in the following therapeutic classes: $35.8 \%(n=5)$, digestive tract and metabolism; $21.5 \%(n=3)$, cardiovascular system; $14.3 \%(n=2)$, nervous system, $7.1 \%(n=1)$ anti-infectives for systemic use; $7.1 \%(n=1)$, anti-parasitic products, insecticides and repellents; $7.1 \%(n=1)$, antineoplastic agents; and $7.1 \%$ $(n=1)$, respiratory system. On medication with a restriction for administration is bisacodyl and is related to loss of effect; as an alternative to it, we have other laxative agents standardized in the institution such as lactulose, mineral oil and sodium phosphate enema. 
Some medications included in the protocol did not appear in data collection because they were standardized after the collection period, for example, methadone (pill) and morphine (pill). Hydroxyurea was also included although it did not appear in data collection with the justification of its potential cytotoxic risk, discussed later.

Ranitidine in pill and syrup presentation appeared in data collection but was not included in the protocol because its production was discontinued by the manufacturer. Therefore, it was no longer used as a therapeutic option in the hospital where the study was conducted.
In the elaboration of the protocol, presented in Table 1, the medications were selected by prescription frequency and, subsequently, a narrative search of the literature was carried out in electronic package inserts from different laboratories, manuals, handbooks, and other scientific references, with the objective of providing information specific to each medication contemplated, since each drug has its own specificities.

Table 1. Prevalence of medication use via tubes and pharmaceutical guidance protocol for preparation and administration of the solid medications most frequently prescribed via enteral catheters or alternatives to this route. (to be continued)

\begin{tabular}{|c|c|c|c|}
\hline $\begin{array}{l}\text { Active ingredient and pharmaceutical } \\
\text { presentation }\end{array}$ & $\begin{array}{l}\text { Prevalence } \\
\mathrm{n}(\%)\end{array}$ & $\begin{array}{l}\text { Recommendations for administration via enteral catheter and source of the } \\
\text { recommendations }\end{array}$ & $\begin{array}{l}\text { Route } \\
\text { exchange }\end{array}$ \\
\hline Acetylcysteine $600 \mathrm{mg}$, granule & $29(1.6)$ & Dilute in $50 \mathrm{~mL}-100 \mathrm{~mL}$ of water. ${ }^{6}$ & $\mathrm{IV}^{5}$ \\
\hline Acetylsalicylic acid 100 mg, p. ${ }^{1}$ & $96(5.3)$ & Dissolve in $10 \mathrm{~mL}$ of water. ${ }^{18}$ & $N A^{8}$ \\
\hline Folic acid $5 \mathrm{mg}, \mathrm{p.}^{1}$ & $25(1.4)$ & Crush and dilute in $15 \mathrm{~mL}$ of water. ${ }^{6}$ & $N A^{8}$ \\
\hline Amiodarone 200 mg, p. ${ }^{1}$ & $73(4.0)$ & Crush with $2 \mathrm{~mL}$ of water to form a paste, add up to $15 \mathrm{~mL}$ of water and mix.18 & $\mathrm{IV}^{5}$ \\
\hline Amitriptyline 25 mg, c. p. ${ }^{2}$ & $20(1.1)$ & Crush and dilute in $15 \mathrm{~mL}$ of water. ${ }^{6}$ & $N A^{8}$ \\
\hline Amlodipine $5 \mathrm{mg}, \mathrm{p}^{1}$ & $98(5.4)$ & Crush and dilute in $10 \mathrm{~mL}$ of water. ${ }^{18}$ & $N A^{8}$ \\
\hline Baclofen $10 \mathrm{mg}, \mathrm{p}^{1}$ & $31(1.7)$ & Crush and dilute in $15 \mathrm{~mL}$ of water. ${ }^{18}$ & $N A^{8}$ \\
\hline Bisacodyl $5 \mathrm{mg}$, c. p. ${ }^{2}$ & $6(0.3)$ & Do not crush: $:^{17}$ loss of enteric coating can inactivate the active ingredient..$^{25}$ & $N A^{8}$ \\
\hline $\begin{array}{l}\text { Calcium, polystyrene sulfonate } 30 \mathrm{mg} \text {, } \\
\text { pow. susp. }{ }^{3}\end{array}$ & $4(0.2)$ & Disperse in $50 \mathrm{~mL}$ of water and shake. ${ }^{27}$ & $N A^{8}$ \\
\hline Captopril $25 \mathrm{mg}$, p. $^{1}$ & $5(0.3)$ & Crush and dilute in $20 \mathrm{~mL}$ of water. ${ }^{6}$ & $N A^{8}$ \\
\hline Carvedilol 3.125/12.5 mg, p. ${ }^{1}$ & $29(1.6)$ & Crush and dilute in $15 \mathrm{~mL}$ of water. ${ }^{6}$ & $N A^{8}$ \\
\hline Clonazepam 0.5/2 mg, p. ${ }^{1}$ & $21(1.2)$ & Disperse in $10 \mathrm{~mL}$ of water and shake for 2 minutes to dissolve. ${ }^{18}$ & $\mathrm{OS}^{7}$ \\
\hline Clonidine $150 \mathrm{mcg}$, p. $^{1}$ & $44(2.4)$ & Disperse for 2 minutes in $10 \mathrm{~mL}$ of water. ${ }^{17}$ & $\mathrm{IV}^{5}$ \\
\hline Clopidogrel 75 mg, c. p. ${ }^{2}$ & $10(0.6)$ & Crush and dilute in $10 \mathrm{~mL}$ of water. ${ }^{6}$ & $N A^{8}$ \\
\hline B Complex, dragée & $13(0.7)$ & Do not crush: difficult solubility coating and high risk of tube obstruction. ${ }^{24,26}$ & $\mathrm{IV}^{5}$ \\
\hline Dexamethasone $4 \mathrm{mg}, \mathrm{p}^{1}$ & $16(0.9)$ & Crush and dilute in $10 \mathrm{~mL}$ of water. ${ }^{18}$ & IV5 Elixir \\
\hline Diazepam 5/10 mg, p. ${ }^{1}$ & $14(0.8)$ & Crush and dilute in $15 \mathrm{~mL}$ of water. ${ }^{6}$ & IV 5 \\
\hline Dipyrone 500 mg, p. ${ }^{1}$ & $7(0.4)$ & Crush and dilute in $15 \mathrm{~mL}$ of water. ${ }^{6}$ & $\mathrm{OS}^{7} \mathrm{IV}^{5}$ \\
\hline Enalapril $10 \mathrm{mg}, \mathrm{p}^{1}$ & $73(4.0)$ & Dissolve under shaking for 5 minutes in $10 \mathrm{~mL}$ of water. ${ }^{18}$ & $N A^{8}$ \\
\hline Scopolamine $10 \mathrm{mg}$, c. p. ${ }^{2}$ & $23(1.3)$ & Crush and dilute in $20 \mathrm{~mL}$ of water (the coating disguises odor and taste).., 25 & $\mathrm{IV}^{5}$ \\
\hline Spironolactone $25 / 100 \mathrm{mg}$, p. $^{1}$ & $70(3.9)$ & Crush and dilute in $15 \mathrm{~mL}$ of water. ${ }^{6}$ & $N A^{8}$ \\
\hline Phenytoin sodium $100 \mathrm{mg}, \mathrm{p}^{1}$ & $77(4.2)$ & $\begin{array}{l}\text { Crush and dilute in } 10 \mathrm{~mL} \text { of water. Monitor serum level because interaction with } \\
\text { enteral nutrition can reduce absorption of the drug by up to } 80 \% \text {. Pause enteral } \\
\text { diet } 1 \text { hour before and } 1 \text { hour after administration. }{ }^{6,25}\end{array}$ & $\mathrm{IV}^{5}$ \\
\hline Phenobarbital sodium $100 \mathrm{mg}$, p. $^{1}$ & $35(1.9)$ & Crush and dilute in $15 \mathrm{~mL}$ of water. ${ }^{6}$ & $\mathrm{IV}^{5} \mathrm{OS}^{7}$ \\
\hline Fluconazole $150 \mathrm{mg}$, capsule & $11(0.6)$ & Open the capsule and wait for the granules to dissolve in $20 \mathrm{~mL}$ of water. ${ }^{6,25}$ & $\mathrm{IV}^{5}$ \\
\hline Fluoxetine $20 \mathrm{mg}$, capsule & $20(1.1)$ & Open the capsule, dilute in $20 \mathrm{~mL}$ of water. ${ }^{18}$ & $N A^{8}$ \\
\hline Furosemide $40 \mathrm{mg}, \mathrm{p}^{1}$ & $24(1.3)$ & Crush and dilute in $10 \mathrm{~mL}$ of water. ${ }^{6}$ & $\mathrm{IV}^{5}$ \\
\hline Hydralazine 25 mg, dragée & $12(0.7)$ & Crush and dilute in $15 \mathrm{~mL}$ of water. ${ }^{6}$ & IV ${ }^{5}$ \\
\hline Hydrochlorothiazide $25 / 50 \mathrm{mg}$, p. $^{1}$ & $40(2.2)$ & Crush and dilute in $15 \mathrm{~mL}$ of water. ${ }^{6}$ & $N A^{8}$ \\
\hline Hydroxyurea 500 mg, hard caps. ${ }^{4}$ & - & $\begin{array}{l}\text { Do not crush: cytotoxic medication that requires a laminar flow hood and the } \\
\text { handler to wear protective equipment.18,27 }\end{array}$ & $N A^{8}$ \\
\hline Ivermectin 6 mg, p. ${ }^{1}$ & $4(0.2)$ & Do not crush: there are no studies on efficacy, safety and pharmacokinetics. ${ }^{25}$ & $N A^{8}$ \\
\hline Levothyroxine 25/50/100 mcg, p. ${ }^{1}$ & $66(3.6)$ & $\begin{array}{l}\text { Crush and dilute in } 10 \mathrm{~mL} \text { of water. Pause diet } 1 \text { hour before and } 1 \text { hour after } \\
\text { administration of the medication. }{ }^{6,25,27}\end{array}$ & $N A^{8}$ \\
\hline Losartan $50 \mathrm{mg}, \mathrm{p.}^{1}$ & $28(1.5)$ & Crush and dilute in $20 \mathrm{~mL}$ of water. ${ }^{18}$ & $N A^{8}$ \\
\hline Methadone $10 \mathrm{mg}, \mathrm{p.}^{1}$ & - & Crush and dilute in $10 \mathrm{~mL}$ of water. ${ }^{6}$ & $N A^{8}$ \\
\hline Metoclopramide $10 \mathrm{mg}, \mathrm{p.}^{1}$ & $10(0.6)$ & Crush and dilute in $15 \mathrm{~mL}$ of water. ${ }^{6}$ & $\begin{array}{l}\text { IV }^{5} \\
\mathrm{OS}^{7}\end{array}$ \\
\hline Metoprolol, succinate $50 \mathrm{mg}, \mathrm{p.}^{1}$ & $10(0.6)$ & $\begin{array}{l}\text { Do not crush: it loses its release characteristics, leading to the risk of inadequate } \\
\text { maintenance of the serum level of the drug. }\end{array}$ & $N A^{8}$ \\
\hline Morphine $10 \mathrm{mg}$, p. $^{1}$ & $1(0.1)$ & Do not crush. ${ }^{6}$ & $\begin{array}{l}\text { IV }^{5} \\
\mathrm{OS}^{7}\end{array}$ \\
\hline Nifedipin $10 \mathrm{mg}, \mathrm{p}^{1}$ & $2(0.1)$ & $\begin{array}{l}\text { Do not crush: the extracted dose may be incomplete and the content can stick to } \\
\text { the tube wall causing obstruction. }{ }^{18} \text { It loses its extended-release characteristic and } \\
\text { the active ingredient is insoluble in water. }{ }^{25}\end{array}$ & $N A^{8}$ \\
\hline
\end{tabular}


Table 1. Prevalence of medication use via tubes and pharmaceutical guidance protocol for preparation and administration of the solid medications most frequently prescribed via enteral catheters or alternatives to this route. (conclusion)

\begin{tabular}{|c|c|c|c|}
\hline $\begin{array}{l}\text { Active ingredient and pharmaceutical } \\
\text { presentation }\end{array}$ & $\begin{array}{l}\text { Prevalence } \\
\text { n (\%) }\end{array}$ & $\begin{array}{l}\text { Recommendations for administration via enteral catheter and source of the } \\
\text { recommendations }\end{array}$ & $\begin{array}{l}\text { Route } \\
\text { exchange }\end{array}$ \\
\hline Omeprazole 20 mg, capsule & $24(1.3)$ & $\begin{array}{l}\text { Do not crush: the institution does not have the appropriate structure for the } \\
\text { preparation of the extemporaneous solution that is required for this medication. }\end{array}$ & $\mathrm{IV}^{5}$ \\
\hline Ondansetron $4 \mathrm{mg}, \mathrm{p.}^{1}$ & $6(0.3)$ & $\begin{array}{l}\text { Do not crush: orally disintegrating medication. There are no specific data for } \\
\text { administration via enteral catheter. }{ }^{17}\end{array}$ & $\mathrm{IV}^{5}$ \\
\hline Paracetamol $500 \mathrm{mg}$, p. $^{1}$ & $8(0.4)$ & Crush and dilute in $10 \mathrm{~mL}$ of water. ${ }^{6}$ & $\mathrm{OS}^{7}$ \\
\hline $\begin{array}{l}\text { Paracetamol 500mg+codeine } 30 \mathrm{mg} \text {, } \\
\text { p. }^{1}\end{array}$ & $15(0.8)$ & Crush and dilute in $10 \mathrm{~mL}$ of water. ${ }^{6}$ & $N A^{8}$ \\
\hline Potassium, chlor. 600 mg, dragée & $5(0.3)$ & $\begin{array}{l}\text { Do not crush: it loses its characteristic of gradual release, in addition to having a } \\
\text { coating that, when crushed, causes tube obstruction. }{ }^{6,24}\end{array}$ & $\mathrm{OS}^{7}$ \\
\hline Prednisone $5 / 20 \mathrm{mg}$, p. $^{1}$ & $6(0.3)$ & Crush and dilute in $10 \mathrm{~mL}$ of water. ${ }^{6}$ & $\begin{array}{l}\mathrm{OS}^{7} \\
\mathrm{IV}^{5}\end{array}$ \\
\hline Promethazine $25 \mathrm{mg}$, c. p. ${ }^{2}$ & $5(0.3)$ & Do not crush: there are no safety or efficacy studies after crushing. ${ }^{24,25}$ & $\mathrm{IM}^{6}$ \\
\hline Propranolol $40 \mathrm{mg}, \mathrm{p}^{1}$ & $52(2.9)$ & Crush and dilute in $10 \mathrm{~mL}$ of water. ${ }^{6}$ & $N A^{8}$ \\
\hline Propatyl nitrate $10 \mathrm{mg}, \mathrm{p.}^{1}$ & $1(0.1)$ & $\begin{array}{l}\text { Do not crush: the medication must } d \text { be administered sublingually. The } \\
\text { therapeutic effect cannot be achieved through the oral route. }{ }^{6}\end{array}$ & $N A^{8}$ \\
\hline Quetiapine 25/100 mg, p. ${ }^{1}$ & $110(6.1)$ & Crush and dilute in $10 \mathrm{~mL}$ of water. ${ }^{6}$ & $N A^{8}$ \\
\hline Risperidone $1 \mathrm{mg}, \mathrm{p}^{1}$ & $19(1.0)$ & Crush and dilute in $10 \mathrm{~mL}$ of water. ${ }^{6}$ & $N A^{8}$ \\
\hline Simvastatin $20 \mathrm{mg}, \mathrm{p.}^{1}$ & $111(6.1)$ & Crush and dilute in $10 \mathrm{~mL}$ of water. ${ }^{6}$ & $N A^{8}$ \\
\hline $\begin{array}{l}\text { Sulfamethoxazole } 400 \mathrm{mg}+ \\
\text { trimethoprim } 80 \mathrm{mg}, \mathrm{p}^{1}\end{array}$ & $3(0.2)$ & $\begin{array}{l}\text { Do not crush: when crushed, the active ingredient and the excipients can cause } \\
\text { tube obstruction. } 6,25\end{array}$ & $\mathrm{OS}^{7}$ \\
\hline Thiamine $300 \mathrm{mg}, \mathrm{p}^{1}$ & $36(2.0)$ & Crush and dilute in $15 \mathrm{~mL}$ of water. ${ }^{6}$ & $\mathrm{IV}^{5}$ \\
\hline Valproic acid $500 \mathrm{mg}$, c. p. ${ }^{2}$ & $13(0.7)$ & $\begin{array}{l}\text { Do not crush: risk of loss of active ingredient and adherence to the tube wall } \\
\text { causing obstruction; active ingredient is aggressive to gastric mucosa. }{ }^{25}\end{array}$ & Syrup \\
\hline
\end{tabular}

${ }^{1}$ pill: p. ${ }^{2}$ coated pill: c. p. ${ }^{3}$ powder for suspension: pow. susp. ${ }^{4}$ capsule: caps. ${ }^{5}$ Intravenous: IV. ${ }^{6}$ Intramuscular: IM. ${ }^{7}$ Oral Solution or Suspension: OS. ${ }^{8}$ Not Available: NA.

\section{Discussion}

Medication prescription and administration via enteral catheters is quite challenging for the entire team, since it involves the practice of many professionals who provide care to the patient. The study by Moreira et al. ${ }^{11}$ (2018) corroborates with the results obtained, presenting most of the medications prescribed in the solid form $(95.8 \%)$, and the liquid presentations had a lower frequency (4.2\%). The paper by Rodrigues et al. ${ }^{3}$ (2014) also presents similar results, obtaining the highest frequency of prescription of solid forms (85\%) and the lowest of liquid forms.

It is to be considered that, since the beginning of the residency in March 2019, there was already pharmaceutical performance regarding the medications that are prescribed via enteral catheters, recommending switching to liquid formulations when available to avoid pill crushing. A number of studies already show that the clinical interventions performed by the pharmacist referring the medical prescription are mostly accepted, and professionals from other classes recognize the importance of the clinical pharmacist's presence in the wards, participating in training and institutional policy changes to ensure that the best practices are followed. ${ }^{4,12}$

In a study carried out in a pediatric hospital that analyzed the classes of medications most frequently prescribed by enteral catheters, the cardiovascular system stood out with $43.1 \%$ of the prescriptions, followed by the digestive tract and metabolism with $20.4 \% .{ }^{13}$ This common result in several studies on the subject matter can be due to the fact that cardiovascular diseases represent the third cause of hospitalization and also to the prevalence of hypertensive patients in the country, corroborating what was found in this study. ${ }^{14,15}$
A major difficulty found during the development of the guidance protocol was the lack of information available from the manufacturers regarding the performance of tests for administration of the medications via enteral catheters. ${ }^{2}$ As well as an information discrepancy between already existing manuals and protocols, explaining the use of empirical recommendations in many situations. ${ }^{4}$

The National Health Surveillance Agency, through Collegiate Directive Resolution No. 63 of July $6^{\text {th }}, 2000$, assures that the enteral catheter is not of exclusive use for enteral nutrition, and can be used for the administration of medications when needed. ${ }^{17}$ As an alternative, empirically, knowing the low availability of medications in an adequate pharmaceutical presentation, solid drugs can be crushed and diluted in water for administration through a tube, excluding this alternative for controlled-release pills, with enteric coating, sublingual or cytostatic. ${ }^{1,5,17}$

Drugs with cytotoxic, carcinogenic and/or teratogenic potential must be crushed and handled properly in a laminar flow hood with the professional's protective equipment on, avoiding any occupational risk. ${ }^{2}$ In the results obtained in this study, hydroxyurea is a medication that fits the cytotoxic profile; therefore, it was included in the protocol as a drug not to be crushed or handled without the necessary structure. ${ }^{17}$

This change of the pharmaceutical presentation can impose risks to the professionals who perform manipulation without a proper technique and can also lead to increased toxicity and to undesirable effects, reduce efficacy, and make it unpalatable and/or unstable.

Crushing pills can increase the absorption speed and plasma concentration of the drug. Therefore, the risk of toxicity related to the dose increases and the duration of the effect is reduced. ${ }^{9}$ 
Despite a known interaction between nutrients and medications, in the hospital environment it is quite common for these to be administered together, although the recommendations are to stop the diet two hours before and two hours after the administration of a medications, readjust the infusion pump for 24 hours, and wash the tube before and after administration. ${ }^{5,18}$

Many of the drug-nutrient interactions can be insignificant from the clinical point of view, but others can exert a considerable impact on the patient. An example is the administration of phenytoin with enteral diet, which presents reduced plasma concentration because its solubility is altered, contributing to increasing the risk of seizures in the patient. ${ }^{5}$ This interaction was observed in this study, and the antiepileptics class in which phenytoin is included was prescribed 205 times (11.32\%).

Other medications included in the protocol presented important interactions with enteral nutrition and their use must be evaluated individually; such is the case of diazepam which, when administered along with nutrition, can have its absorption increased, with risk of toxicity or overdose. The absorption of captopril is reduced by $30 \%$ to $40 \%$ when interacting with enteral nutrition, and clopidogrel has interactions that are benefitial to the patient, because its concomitant administration with enteral nutrition reduces the gastrointestinal effects. These situations must be assessed by the clinical pharmacist and discussed with the physician. ${ }^{15,24}$

So that the interactions can be reduced, the Nursing team must pay attention to the irrigation of the tubes and observe granule or gel formation that can cause tube obstruction. ${ }^{5}$ The clinician must also be aware of the likelihood of interactions when prescribing medications by the alternative feeding route, just as the pharmacist is tasked with alerting and guiding the team as to the possible risks of obstruction or relevant interactions. Thus, the entire team can be attentive and aware of the potential complications and limitations associated with this method. ${ }^{5,14}$

An especially important complication is tube obstruction, which can occur due to the crushing of controlled-release or enteric-coated medications or the preparation of more than one drug in the same container. It will be necessary to change the tube, meaning pain and discomfort to the patient, rework for the team, and a reduction in quality of care due to the risk of greater complications in the patient's clinical condition. ${ }^{5,19}$

Important medications analyzed can cause tube obstruction, such as nifedipine, whose active ingredient is not soluble in water; potassium chloride dragées contain a coating which, after crushed, can also obstruct the tube, as can valproic acid.

When there is no other standardized pharmaceutical presentation or other substitute medication, such as the case of metoprolol, a risk-benefit assessment and discussion between the clinical pharmacist and the prescribing physician is always of utmost importance to minimize possible effects that may harm the therapy and the patient's health.

Studies developed with this topic highlight many difficulties in drug administration, as well as many errors in the preparation and administration procedure, reinforcing the need for standardized recommendations. ${ }^{20,21}$ It is essential and urgent to implement care measures in the process of preparation and administration of medications through enteral catheters, which enables safety and quality in drug therapy.

In this way, a safer and more rational way can be the standardization of the liquid pharmaceutical presentations of these drugs, in addition to bringing benefits such as treatment compliance, ease of administration and reduction of unnecessary losses, reflecting in cost reduction. ${ }^{1}$

In addition, Moriel et al. ${ }^{2}$ (2012) state that there are several unwanted adverse effects that can be caused by excipients and by the high osmolarity of some liquid preparations. The most commonly used excipients are ethanol, glycerol, propylene glycol and sorbitol, the latter of which can cause diarrhea. ${ }^{2}$

In this context, updating of the pharmacist and access to reliable information are indispensable. The increasing acceptance of the pharmaceutical interventions in this area, and considering that the role of this professional together with the multidisciplinary team is ensured by law, proves that the pharmacist is the most qualified professional to clarify doubts and solve problems related to medications. ${ }^{3}$

In this way, the pharmacist ceases to be only a technical holder of knowledge and starts to act in the clinical practice integrated to the team as a reference for the pharmacotherapeutic needs. $3,14,15,22$

\section{Conclusion}

This study showed the importance of the performance of the clinical pharmacist in the guidance of the multi-professional team in patients who are using an enteral catheters, and the articulation of this team in face of each particularity when it is necessary to use medication via this route, aiming at the quality of care provided to the patient.

The result of this paper is extremely relevant to guide other professionals of the assistance team so that the use of these medications is no longer performed empirically, thus ensuring quality, efficacy, and safety in drug therapy.

\section{Funding sources}

The authors declare that the research did not receive funding for its conduction.

\section{Collaborators}

$\mathrm{DB}$ and PMOL devised the project; $\mathrm{DB}$ conducted data collection, data interpretation and writing of the article. $\mathrm{DB}$ and PMOL critically reviewed the article. All the authors approved the final version to be published and are responsible for all the information contained in the article, ensuring the accuracy and integrity of any its parts.

\section{Acknowledgments}

To the Dr. Homero de Miranda Gomes Regional Hospital of São José, which made it possible to conduct the research and to develop the study. 


\section{Conflict of interest statement}

The authors declare that there are no conflicts of interest regarding this article.

\section{References}

1. Nunes MS, Valença RCA, Gurgel RKC, et al. Análise das solicitações de comprimidos adaptados para pacientes críticos de um hospital universitário. Rev Bras Farm Hosp Serv Saúde. 2013;4(4) 23-30.

2. Moriel P, Shoji P, Bortoletto TC, et al. Uso off label de medicamentos através de sondas: divergência entre informações. Rev Bras Farm Hosp Serv Saúde. 2012;3(2):20-24.

3. Rodrigues JB, Martins FJ, Raposo NRB et al. Perfil de utilização de medicamentos por sonda enteral em pacientes de um hospital universitário. Rev Bras Farm Hosp Serv Saúde. 2014;5(3):23-27.

4. Alhashemi SH, Ghorbani R, Vazin A. Improving Knowledge, attitudes, and practice of nurses in medication administration through enteral feeding tubes by clinical pharmacists: a case-control study. Advances in Medical Education and Practice. 2019:10 493-500. DOI: 10.2147/AMEP.S203680

5. Lopes DMA, Gomes EV, Madeira LS, et al. Revisão sobre o uso de fármacos através de sondas digestivas: um estudo de base hospitalar. Rev Bras Farm Hosp Serv Saúde. 2013; 4(2):6-13.

6. Ferrer R, Joaquim FM, Pavan AM et al. Manual de diluição e administração de medicamentos por acessos enterais. Braspen Journal. 2019;34 (2):193-212.

7. Minuzz AP, Salum NC, Locks MOH. Avaliação da cultura de segurança do paciente em terapia intensiva na perspectiva da equipe de saúde. Texto Contexto Enferm. 2016; 25(2):e1610015.DOI:10.1590/0104-07072016001610015

8. Siman AG, Braga LM, Amaro MOF, et al. Desafios da prática na segurança do paciente. Rev Bras Enferm. 2019;72(6):1581-8. DOI: 10.1590/0034-7167-2018-0441.

9. Sari D, Kadifeli D, Akbiyik A, et al. Intensive care unit nurses' knowledge of medication administration via enteral tubes. Nurs Crit Care. 2018 May;23(3):141-146. DOI: 10.1111/nicc.12335.

10. WHO Colaborating Centre for Drugs Statistics Metodology. Índice ATC/DDD. Available in: https://www.whocc.no/atc_ ddd_index/ Accessed on: 10 maio de 2020.

11. Moreira MAJ, Figueiredo PP, Silveira RS, et al. Profile of medicines used via oral and gastrointestinal catheter in a Walk-in Service. Rev Esc Enferm USP. 2018;52:e03385. DOI: 10.1590/ s1980-220x2017037103385.

12. Medeiros RDA, Moraes JP. Intervenções farmacêuticas em prescrições médicas na unidade de terapia intensiva. Rev Bras Farm Hosp Serv Saúde. 2014; 5(2): 26-29.

13. Marinho RNA, Cabral CHK. Estudo de adaptações de formulações farmacêuticas em um hospital universitário pediátrico. Rev Bras Farm Hosp Serv Saúde. 2014;5(3): 12-17.

14. Santos GF, Pinto JDM, Vasconcelos FF, et al. Caracterização dos medicamentos administrados por sonda de nutrição e as possíveis interações fármaco-nutrição enteral. Rev Bras
Farm Hosp Serv Saúde. 2017;8(3):31-36.DOI:10.30968/ rbfhss.2017.083.006

15. Basso AP, Pinheiro MS. Avaliação dos medicamentos prescritos para pacientes submetidos à terapia nutricional enteral no CTI. Rev Bras Farm Hosp Serv Saúde. 2014;5(1): 12-18.

16. Ministério da Saúde. Agência Nacional de Vigilância Sanitária. Resolução de Diretoria Colegiada no 63 de 6 de julho de 2000. Brasil. Available in: https://bvsms.saude.gov.br/bvs/saudelegis/anvisa/2011/rdc0063_25_11_2011.html Accessed on: 10 de maio de 2020.

17. White R, Bradnam V. Handbook Of Drug Administration via enteral feeding tubes, 3 edição. Londres: Pharmaceutical Press; 2015.

18. Souza J, Silva JAC, Langaro E, et al. Interação fármaco-nutrientes em unidade de terapia intensiva. Braspen Journal. 2017;32(3):226-30.

19. Lima G, Negrini NMM. Assistência farmacêutica na administração de medicamentos via sonda: escolha da forma farmacêutica adequada. Hospital Israelita Albert Einstein. 2009; 7(1Pt 1):9-17.

20. Caussin M, Mourier W, Philippe S, et al. Crushing drugs in geriatric units: an "handcraft" practice with frequent errors which imposed recommendations. Rev Med Interne. 2012;33(10):546-551.DOI:10.1016/j.revmed.2012.05.014.

21. Spezia, I. A., \& Matheus, F. C. Evaluation of prescription containing medication via enteral feeding tubes in an adult emergency unit. Rev Bras Farm Hosp Serv Saúde. 2020;11(4):497. DOI:10.30968/rbfhss.2020.114.0497

22. Santos CM, Costa JM, Netto MUQ, et al. Acompanhamento farmacoterapêutico de pacientes em uso de sonda nasoenteral em um hospital de ensino. Rev Bras Farm Hosp Serv Saúde. 2012;3(1): 19-22.

23. Hospital Regional São Paulo. Protocolo de administração de medicamentos sólidos via sonda. Xanxerê. 2019.

24. Universidade Federal de Grande Dourados. Recomendações para administração de medicamentos via sonda. Ebserh. 2017;1-17.

25. Souza GA. Preparo e administração de medicamentos via sonda em um Centro de Terapia Intensiva de um Hospital Público. Universidade de São Paulo, Ribeirão Preto, 2016.

26. Agência Nacional de Vigilância Sanitária. Anvisa. Bulário eletrônico. Available in: https://www.anvisa.gov.br/datavisa/ fila_bula/frmResultado.asp. Accessed on: 23 de agosto de 2020. 